\title{
Animal Breed Code
}

National Cancer Institute

\section{Source}

National Cancer Institute. Animal Breed Code. NCI Thesaurus. Code C93724.

A coded value specifying a group of animals presumably related by descent from common ancestors and visibly similar in most characters. 